\title{
Leydig cell testicular tumour presenting as isosexual precocious pseudopuberty in a 5year-old boy
}

\begin{abstract}
Leydig cell testicular tumors are very rare in children and cause isosexual precocious puberty. We report on a 5-yr-old boy with a Leydig cell tumor of the test is presented with isosexual precocious puberty, penis enlargement, pubic hair, recent growth spurt with deeping of the voice and a seven years on his bone age. An elevated testosterone level $3.72 \mathrm{ng} / \mathrm{mL}$. Right testicle ultrasound showed a hypoechoic nodule and right orchiectomy was performed.
\end{abstract}

Keywords: leydig-cell tumor, testicular, precocious puberty, neoplasm, testis

\author{
Volume 5 Issue I - 2017
}

\section{Sandra Yesenia Castillo Orihuela, Karol Elizabeth Valle Cabanillas \\ Area of Pediatric Endocrinology, Hospital de Alta Complejidad Virgen de La Puerta, Perú}

\begin{abstract}
Correspondence: : Sandra Castillo Orihuela, Pediatric Endocrinology. Department of Pediatric, Hospital de Alta Complejidad Virgen de La Puerta,Trujillo, Perú,

Email sandracas80@hotmail.com
\end{abstract}

Received: May 14, 2017| Published: June 23, 2017

\section{Introduction}

Precocious puberty is defined as the appearance of secondary sex characteristics at a younger age than in the general population, 8 year old in girls and 9years old in boys as the lowest age of normal puberty. ${ }^{1,2}$ Precocious puberty can occur because of a disturbance in hypothalamic pituitary gonadal axis (which is called central precocious puberty), or a disturbance outside that axis (which is called peripheral precocious puberty). ${ }^{3}$

Testicular tumors are rare in pediatric patients with an incidence of $0.5-2 / 100,000$ children and adolescents. ${ }^{4}$ Leydig cell tumors are sex cord Stromal Tumors arising from Leydig cells that are interstitial cells that produce testosterone. ${ }^{5}$ They represent the 1-3\% of all tumors and more commonly found in adults between 40 and 50 years of age. Leydig cell tumors are universally benign during childhood. The majority of patients present between 5 and 10year of age, most commonly with precocious puberty. ${ }^{6}$ Androgenization signs include prominent external genitalia, frequent erections, pubic and axillary hair, early growth spurt and deepening of the voice. ${ }^{7}$ An elevated testosterone level with low or normal serum gonadotropin, FSH (follicle-stimulating hormone) and LH (luteinizing hormone), levels is consistent with Leydig cell tumor. Ultrasonography is necessary for diagnosis because it is sometimes difficult to detect on physical examination. ${ }^{8}$ Leydig cell tumors should be treated by simple orchidectomy. Testis-sparing excision is a reasonable consideration when the volume of normal testicular tissue surrounding the mass is acceptable or the lesion is bilateral. ${ }^{9}$

\section{Case report}

A 5-yr-old boy was referred to the hospital for endocrinology pediatric evaluation of penis enlargement, pubic hair, axillary odor and recent growth spurt with deeping of the voice for over one year. The parents noticed a penis enlargement with pubic hair and frequent erections (Figure 1).

Anthropometric parameters in the first evaluation at 5year and 6 months years old, weight: $20.5 \mathrm{~kg}$, height: $119 \mathrm{~cm}$.

The clinical examination revealed prominent external genitalia with pubic hair stage 3 of tanner, right testis with volume of 5 $\mathrm{cc}$ and left testicle volume of 1cc (Figure 1), with no palpable delimitated tumor mass in the right testicle. The age of radiological bone according to Greulich and Pyle was 7 to $6 \mathrm{~m}$ (2years above chronological age) (Figure 2). The levels of testosterone was $3.72 \mathrm{ng} / \mathrm{ml}$, the levels of FSH and LH were prepuberal.

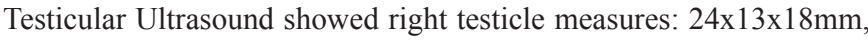
heterogeneous hypoechogenic nodule measuring $22 \times 10 \times 20 \mathrm{~mm}$ with peripheral vascularization suspicious of malignancy. Left testicle measures: 10x7x15mm, homogeneous epididymis having cystic image of $2 \times 2 \mathrm{~mm}$.

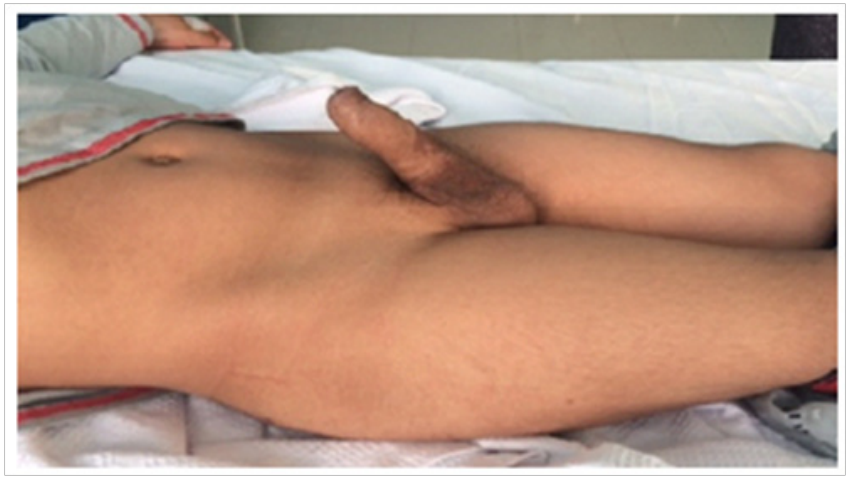

Figure I The 5-yr-old patient showing a prominent external genitalia.

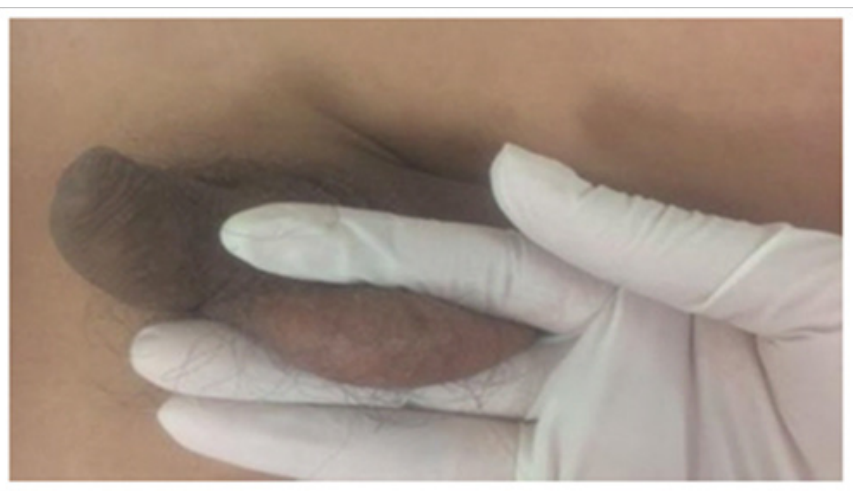

Figure 2 Enlargment of right testicle volumen. 
The chest x-ray and the abdominal - pelvic MRI were normal Following referral to the Urology Team of the hospital, the patient underwent right radical inguinal orchidectomy and pathology examination of the right testis of $4 \times 3 \times 2.2 \mathrm{~cm}$ revealed a wellcircumscribed encapsulated solid nodule of $2.1 .8 \times 2 \mathrm{~cm}$, the cut surface was beige with yellowish central area and firm consistency (Figure 3). Immunohistochemically, vimentin and inhibin were expressed in the cytoplasm of the tumor's cells, the KI67 were less than $1 \%$ compatible with tumor cells of Leydig (Figure 4).
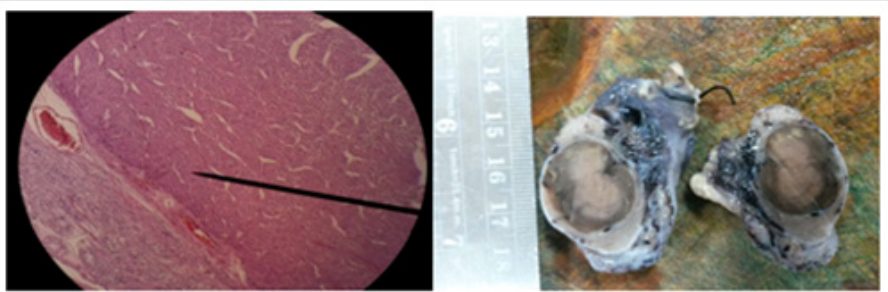

Figure 3 Macroscopic appearance of the tumour \& Microscopic characteristics of Leydig cell tumor.

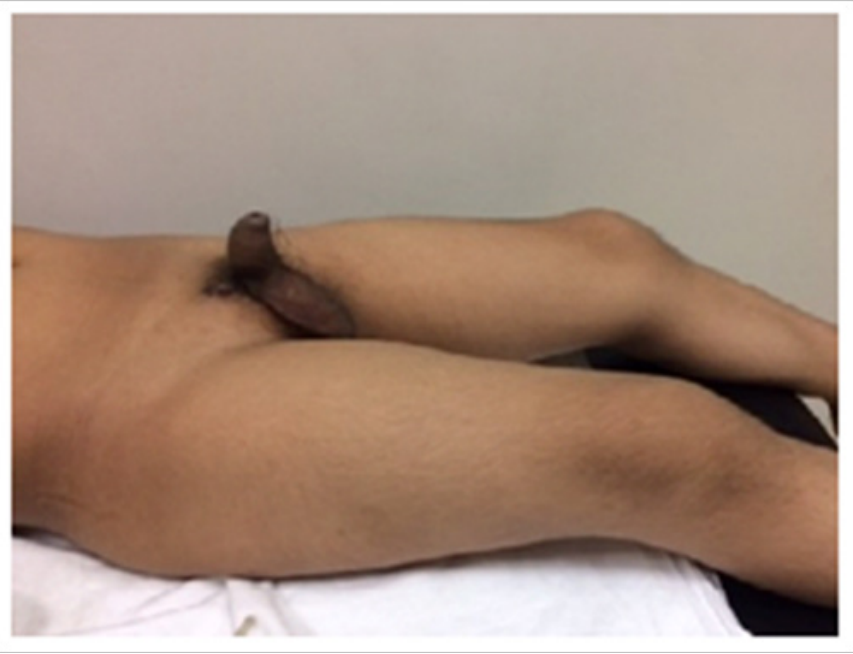

Figure 4 The 5-yr-old patient after surgery.

\section{Discussion}

This case is attached to the few reported cases of children with peripheral precocious puberty secondary to testicular Leydig cell tumor. Leydig cell tumors are rare in children and originate from the gonadal stroma, they comprise of $1 \%$ to $3 \%$ of all testicular tumors, it has two maximum peaks of presentation: in pre-puberal children and in adults between the third and fourth decade of life. ${ }^{10}$ The clinical presentation of tumors of Leydig cells in children is characterized by isosexual precocious pseudopuberty associated with increased testosterone, low gonadotropin levels and testicular palpable mass. ${ }^{11}$ Precocious pseudopuberty refers to development of secondary sex characteristics in the absence of hypothalamic-pituitary modulation due to abnormal production of sex hormones. Diverse sex steroidproducing entities could cause isosexual precocity. The clinical characteristics include rapidly somatic growth spurt, pubic and axillar hair, facial acne, painful erections, penis enlargement and deep voice. ${ }^{12-14}$ In the blood samples an elevated level of androgens, primarily testosterone, and normal or low levels of gonadotropins; patients develop secondary sexual characteristics, in the absence of the activation of the hypothalamic-pituitary axis as in our case, the values of age serum pituitary hormones were normal for his age, however, the serum value of testosterone was high with negative tumour markers (alpha-fetoprotein beta-HCG, LDH), therefore, it is necessary to make hormone study that includes testosterone, prolactin, estradiol, FSH and LH (Table 1). Ultrasound examination of Leydig cell tumors typically reveals a solid hyperechogenic mass that is well differentiated with respect to the surrounding parenchyma. Microscopically these tumors are characterized by a diffuse and solid pattern of growth with large polygonal cells containing eosinophilic cytoplasm. One third of the cases show the typical Reinke's crystalloids of cytokeratin. Immunohistochemically, vimentin, Melan A and inhibin are expressed in the cytoplasm of the tumor cells. Proliferative index defined by MIB 1 expression is usually moderate. ${ }^{13-15}$ Although Leydig cell tumors are usually benign, about $10 \%$ of the reported cases evolve into a malignant neoplasm. The only certain criterion for malignancy is metastasis, and that is why follow-up must be prolonged. ${ }^{16,17}$ The treatment for this type of lesion is radical orchidectomy by inguinal approach with clamping of the spermatic cord associated with lymphadenectomy when regional nodes are involved. Long-term follow-up is necessary in all cases after surgery, even after radical surgery.

Table I Blood samples were subjected to laboratory tests, including measurement of the levels of $\mathrm{FSH}, \mathrm{LH}$ and testosterone hormones

\begin{tabular}{ll}
\hline LH & $0.1 \mathrm{IU} / \mathrm{L}$ \\
FSH & $0.1 \mathrm{IU} / \mathrm{L}$ \\
Free Testosterone & $20.87 \mathrm{pg} / \mathrm{mL}$ (NR: 0.1-3.2). \\
Total Testosterone & $3.72 \mathrm{ng} / \mathrm{mL}$ (NR: 0.03-0.68). \\
I7-OHP & $2.59 \mathrm{ng} / \mathrm{ml}(\mathrm{NR}: 0.07-1.7)$ \\
AFP & $0.828 \mathrm{ng} / \mathrm{mL}$ \\
B HCG & $0.1001 \mathrm{U} / \mathrm{L}$ \\
ACTH & $13.94 \mathrm{pg} / \mathrm{ml}$ \\
Cortisol & $5.88 \mathrm{ug} / \mathrm{dl}$ \\
Prolactin & $23.60 \mathrm{ng} / \mathrm{mL}$ \\
Lactic Dehydrogenase & $447 \mathrm{U} / \mathrm{L}(\mathrm{NR}: 110-295)$ \\
Estradiol & $19,13 \mathrm{pg} / \mathrm{mL}$ \\
\hline
\end{tabular}

The surgical removal of the tumor mass, defines the curative treatment with regression of the clinical characteristics of puberty, however, in some cases has been the development of central precocious puberty after surgery. Although the pathogenesis of this situation is unknown, it has been proposed that exposure to high concentrations of testosterone induces early maturation of the pulse generator of gonadotropins in the hypothalamus hormone. ${ }^{18}$

In summary, we recommend a prompt scrotal ultrasound scan when precocious puberty is diagnosed, even in the absence of a palpable testicular mass. The recommended treatment is unilateral orchidectomy or testis-sparing surgery in selected cases.

\section{Acknowledgments}

None.

\section{Conflicts of interest}

The authors declare that there is no conflict of interest. 


\section{References}

1. Verrotti A, Penta L, Zenzeri L, et al. True precocious puberty following treatment of a Leydig cell tumor: two case reports and literature review. Front Pediatr. 2015;3:93-98.

2. Temboury normal pubertal development. Precocious puberty. Rev Pediatr Aten Prim. 2009;11:127-142.

3. Valdivia F. precocious puberty: experience in 48 cases. Anal FAC med. 1997;58:105-8.

4. Taskinen S, Fagerholm R, Aronniemi J, et al. Testicular tumors in children and adolescents. J Pediatr Urol. 2008;4(2):134-137.

5. Adelman WP, Joffe A. Consultation with the specialist: testicular masses/ cancer. Pediatr Rev. 2005;26(9):341-344.

6. Alonso FJ, Osorio VA. Leydig cell tumor presenting as precocious pseudopuberty in a 4-year-old boy. Arch Esp Urol. 2004;57(4):426-428.

7. Criscuolo T, Sinisi AA, Perrone L, et al. Isosexual precocious pseudopuberty secondary to a testosterone- January 2010 Leydig Cell Testicular Tumour 23 secreting Leydig cell testicular tumour: true isosexual development early after surgery. Andrologia. 1986;18:175-183.

8. Ilondo MM, van den Mooter F, Marchal G, et al. A boy with Leydig cell tumour and precocious puberty: ultrasonography as a diagnostic aid. Eur J Pediatr. 1981;137(2):221-227.

9. Metcalfe PD, Farivar-Mohseni H, Farhat W, et al. Pediatric testicular tumors: contemporary incidence and efficacy of testicular preserving surgery. J Urol. 2003;170(6 Pt 1):2412-2415.
10. Rajput R, Bhansali, Bhat R, et al. Precocious Pseudopuberty with Testicular Enlargement. Clinical Brief. 2006;3(4):356-358.

11. Carmignani L, Salvioni R, Gadda F, et al. Long-term followup and clinical characteristics of testicular Leydig cell tumor: experience with 24 cases. J Urol. 2006;176(5):2040-2043.

12. Kaufman E, Akiya F, Foucar E, et al. Viralization due to Leydig cell tumor diagnosis by magnetic resonance imaging. Case management report. Clin Pediatr (Phila). 1990;29(7):414-417.

13. Kirsch AJ, Bastian W, Cohen HL, et al. Precocious puberty in a child with uninilateral Leydig cell tumor of the test is following orchiopexy. $J$ Urol. 1993;150(5Pt 1):1483-1485.

14. Polepalle SK, Shabaik A, Alagiri M. Leydig cell tumor in a child with spermatocyte maturation and no pseudoprecocious puberty. Urology. 2003;62(3):551-552.

15. Canda AE, Atmaca AF, Ozdemir AT, et al. Testis sparing surgery for sequential bilateral testicular tumors. Can J Urol. 2009;16:4677-4681.

16. Jou P, Maclennan GT. Leydig cell tumor of the testis. $J$ Urol. 2009;181:2299-2300.

17. Petkovic V, Salemi S, Vassella E, et al. Variable clinical presentation, diagnostic features, follow-up and genetic analysis of four cases. Horm Res. 2006;67:89-95.

18. Pastor H, Donate M, Carrion P, et al. Current status of the diagnosis and treatment of testicular Leydig cell tumor. Contribution of two cases. Arch Esp Urol. 2008;61(1):27-33. 